Short Communication

\title{
Estimating Total Phenolics in Taraxacum officinale (L.) Extracts
}

\author{
Ahmad Saeed Khan', Khalid Arif ${ }^{2}$, Bushra Munir ${ }^{3}$, Shumaila Kiran ${ }^{4}$, Fatima Jalal \\ Naseem Qureshi', Syeda Mona Hassan ${ }^{6}$, Gul Afshan Soomro ${ }^{7}$, Arif Nazir ${ }^{8 *}$, \\ Abdul Ghaffar ${ }^{3 * *}$, Muhammad Asif Tahir9, Munawar Iqbal ${ }^{8}$ \\ ${ }^{1}$ Department of Chemistry, Karakoram International University, Gilgit-Baltistan, Pakistan \\ ${ }^{2}$ Department of Mathematics \& Statistics, The University of Lahore, Lahore, Pakistan \\ ${ }^{3}$ Department of Biochemistry, Government College University, Faisalabad, Pakistan \\ ${ }^{4}$ Department of Applied Chemistry, Government College University, Faisalabad, Pakistan \\ ${ }^{5}$ Department of Zoology, Government College University, Faisalabad, Pakistan \\ ${ }^{6}$ Department of Chemistry, Lahore Garrison University, Lahore, Pakistan \\ ${ }^{7}$ Institute of Chemistry, Shah Abdul Latif University, Khairpur, Sindh, Pakistan \\ ${ }^{8}$ Department of Chemistry, The University of Lahore, Lahore-Pakistan \\ ${ }^{9}$ Department of Chemistry, University of Agriculture, Faisalabad, Pakistan
}

Received: 23 August 2017

Accepted: 9 October 2017

\begin{abstract}
This study focuses on evaluating total phenolic contents (TPC) in Taraxacum officinale (L.), a member of the family Asteraceae (compositae). The TPC were estimated by Folin-Ciocalteu's reagent and gallic acid was taken as standard. The amount of phenolics was communicated as gallic acid equivalent (GAE). The TPC varied from $41.47 \mathrm{mg} / \mathrm{g}$ to $691.6 \mathrm{mg} / \mathrm{g}$ in the Taraxacum officinale (L.) extracts. The maximum phenolic contents were found in hydro-alcoholic extract (691.6 mg/g GAE) in comparison with aqueous extract. These extracts have a significant role as antibacterial and antimicrobial agents.
\end{abstract}

Keywords: phenolic, Asteraceae, medicinal, Taraxacum officinale, Gilgit-Baltistan

\section{Introduction}

South Asia is a region that is considered home for Ayurveda treatment along with other very traditional systems. Medicinal plants are the central resources for health care systems and more than 6,000 plant species have been reported for medicinal purpose in the region [1]. The plant-driven medicines have been used on a large

*e-mail: anmalik77@gmail.com

** e-mail: aghaffaruaf@yahoo.com scale owing to their safe nature and cheap availability [2]. These phytochemicals, to some extent, act as an inspirational source for novel drug development [3]. Mountainous regions provide a naturally conducive environment for medicinal flora [4]. According to Noor et al. [5] the knowledge of medicinal plants and their methods of use are confined to aged persons above 50-60 years old. Some of the plants have been tested for their antimicrobial activity and were found to be positive [6-9].

Taraxacum officinale (L.) is the common dandelion - a flowering herbaceous perennial herb found mostly in temperate regions around the world. Taraxacum officinale 


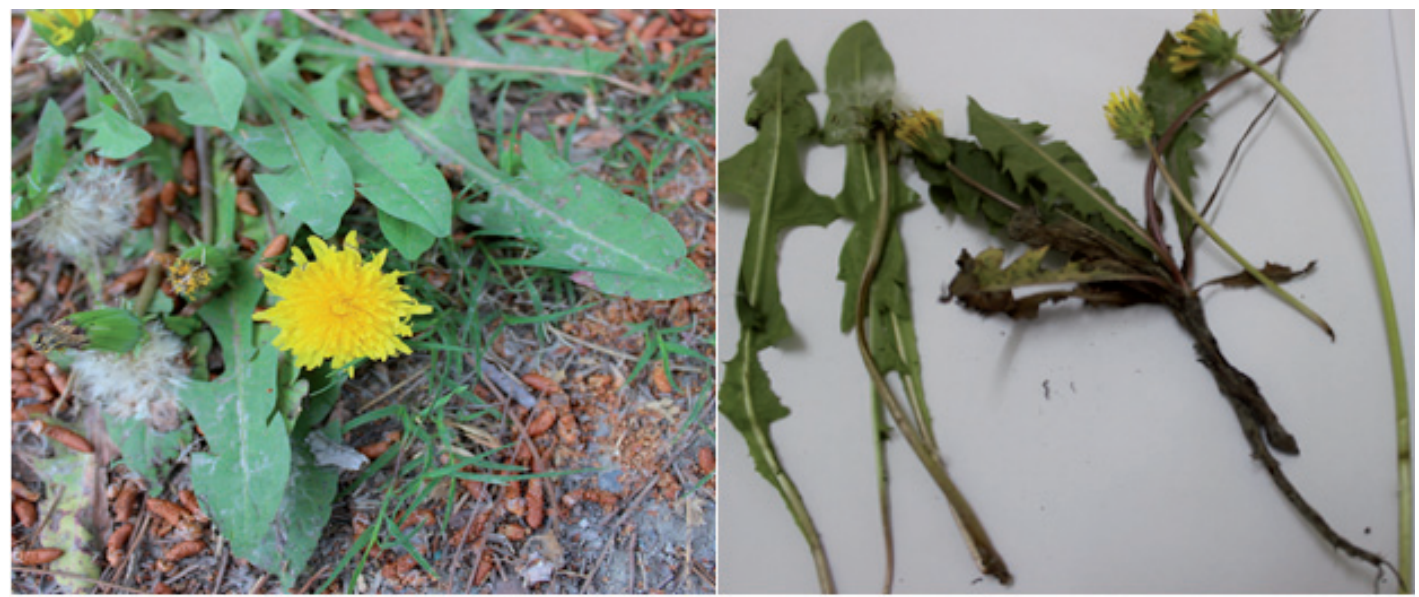

Fig. 1. Taraxacum officinale showing habitat and roots.

produces stems that are typically $5-40 \mathrm{~cm}$ tall, though in some cases it may grow up to $70 \mathrm{~cm}$ high. The foliage may be upright-growing or horizontally spreading. The plant is characterized by hairy stems, milky latex, and basal leaves (Fig. 1) with one single flower head. The flower heads are ligulate and bisexual. The leaves are obovate in shape with strident or gentle teeth [10].

Although in general Taraxacum officinale is regarded as a weed, it is highly valuable for medicinal applications. Mainly it is considered a diuretic, laxative tonic for rheumatic problems and a blood purifier. Dandelion is one of the few apomictic plants that can reproduce asexually and survive practically anywhere [11-16]. Extensive research on the role of free radicals as both toxic and beneficial species has been conducted. There are various activities in which free radicals are generated in our environment. Their presence in higher concentrations can damage all macromolecules and eventually cause cell death. Free radicals have applications in a variety of ways and for curing multiple diseases like atherosclerosis, cancer, and heart disease [17-19]. Aerobic life has an evolved mechanism to protect them from destroying actions of free radicals. Oxidative stress and free radical overproduction has been the cause of numerous diseases. The phytochemicals possess multiple bioactive properties, including antioxidant potential owing to the presence of phenolic compounds. The need of the hour is to understand the mechanism of action, the establishment of therapeutic doses, the occurrence of biochemical inter-relations, bioavailability, and bio-efficacy of theses phytochemicals [20-22]. The purpose of our current study was to estimate TPC of Taraxacum officinale quantitatively using Folin-Ciocalteu's reagent.

\section{Materials and Methods}

The plant specimens were collected from different localities in Gilgit-Baltistan and plant extracts were prepared in two different ways, i.e., pure water and a 1:1 mixture of water with ethanol. For hydro-alcohol extract, $20 \mathrm{~g}$ of the powdered plant material (leaves) was extracted with $250 \mathrm{ml}$ of ethanol:water (1:1) mixture) for 8 hours with reflux at $50^{\circ} \mathrm{C}$. After filtration it was evaporated to dryness, to give the crude extract and the same was repeated for aqueous extract.

\section{Procedure for Determining TPC}

TPC was determined quantitatively following the procedure described in Lim et al. [23]. Different concentrations $(0.01,0.02,0.03,0.04$, and $0.05 \mathrm{mg} / \mathrm{ml})$ of gallic acid and plant extracts $(0.1$ and $1 \mathrm{mg} / \mathrm{ml}$ ) were prepared in methanol. $0.5 \mathrm{ml}$ of each sample was mixed with $2.5 \mathrm{ml}$ of (10 times dilute) Folin-Ciocalteu's reagent and $2 \mathrm{ml}$ of $(7.5 \%)$ sodium carbonate $\left(\mathrm{Na}_{2} \mathrm{CO}_{3}\right)$ and stabilized for half an hour at ambient temperature. The absorbance was measured at $760 \mathrm{~nm}$ spectrophotometrically in triplicate [24-25]. The standard gallic acid curve was prepared through a similar procedure. Stock solution was prepared by dissolving $10 \mathrm{mg}$ of gallic acid in $10 \mathrm{ml}$ methanol. $0.8,1.6,3.12,6.25,12.5$, and $25 \mu \mathrm{g} / \mathrm{ml}$ concentrations were managed from this stock solution. The absorbance of each solution was measured in a similar way as mentioned above. The TPC of the extracts were calculated by the regression equation of the calibration curve $\left(\mathrm{y}=0.024 \mathrm{x}+0.370 ; \mathrm{R}^{2}\right)$.

Table 1. Absorbance measurement of Gallic Acid.

\begin{tabular}{|c|c|c|c|c|c|}
\hline S. No. & 1 & 2 & 3 & 4 & 5 \\
\hline Concentration of solution $(\mu \mathrm{g} / \mathrm{ml})$ & 0.128 & 0.256 & 0.499 & 1.0 & 2.0 \\
\hline Absorbance $\lambda_{\max }=760 \mathrm{~nm}$ & 0.3393 & 0.3506 & 0.4613 & 0.548 & 0.8066 \\
\hline
\end{tabular}




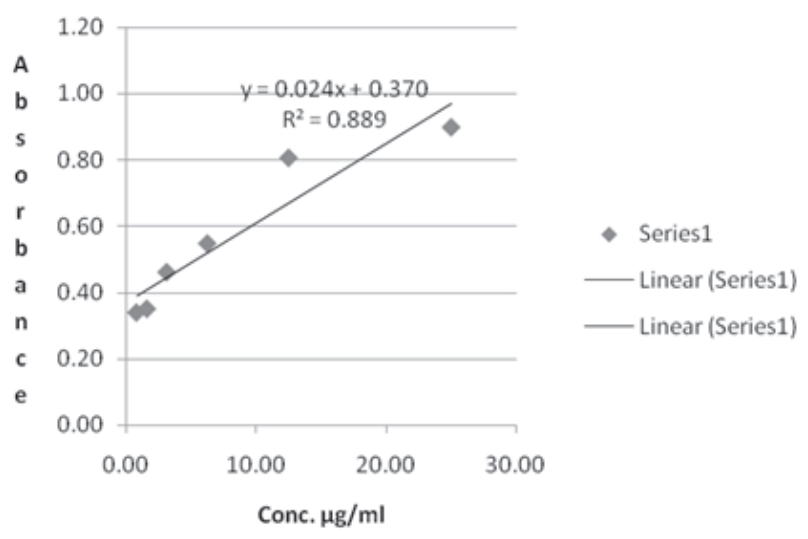

Fig. 2. Standard curve of gallic acid.

\section{Results and Discussion}

The medicinal plant Taraxacum officinale (L.) was analyzed for antioxidant activity through TPC determination using a UV-visible spectrophotometric technique based on Folin-Ciocalteu's phenol reagent. The activity was calculated as GAE. The absorbance of gallic acid solutions is shown in Table 1.

The Gallic acid standard curve was obtained by plotting the absorbance on y-axis and concentration $(\mu \mathrm{g} /$ $\mathrm{ml}$ ) on x-axis. The absorbance of gallic acid increases with increased concentration and a straight line is obtained. The standard curve of gallic acid is shown in (Fig. 2). Taraxacum officinale was examined for phenolic content using Folin-Ciocalteu's method. According to the results, the hydro-alcoholic extract showed high value of phenolic content, whereas aqueous extract showed a comparatively low value in phenolic content (Table 2).

The total phenolic contents were expressed as $\mathrm{mg} / \mathrm{g}$ GAE. The standard curve equation is $y=0.024 x+0.370$, $\mathrm{R}^{2}=0.889$, where $\mathrm{y}$ is absorbance at $760 \mathrm{~nm}$ and $\mathrm{x}$ is total phenolic content in different extracts (Fig. 2). Phenolics are a large group of antioxidants that act as a free radical terminator [26-30]. Table 1 shows the disparity of absorbance with gallic acid concentration.

Table 2 shows the TPC in Taraxacum officinale, ethanolic-aqueous (50-50), and aqueous extracts. The TPC exhibited variation between $20.73 \pm 4.98$ to $38.45 \pm 3.92 \mu \mathrm{g} / \mathrm{ml}$ in the extracts that were $41.47 \mathrm{mg} / \mathrm{g}$ and $691.6 \mathrm{mg} / \mathrm{g}$ GAE, respectively. The results showed the difference in values of TPC of Taraxacum officinale in hydro-alcoholic and aqueous extracts. The hydroalcoholic extract has contained high values of phenolics content $(691.6 \mathrm{mg} / \mathrm{g})$, whereas the aqueous extract had low values of TPC $(41.47 \mathrm{mg} / \mathrm{g})$.

Malek and Legath [31] also determined the antioxidant capacity. They found $362.14 \pm 6.76 \mu \mathrm{M}$ quantities of total phenolics in the extracts of Taraxacum officinale. Ivanov [32] found maximum quantities of TPC in 50\% ethanol extract of $T$. officinale leaves: $33.90 \pm 0.57 \mathrm{mg}$ GAE/g dry weight. This value is near our TPC value in aqueous extract, i.e., $41.7 \mathrm{mg} / \mathrm{g}$ GAE.

Today it is vital to develop reliable and cost-efficient antimicrobial agents for a safe environment and good health. It has become a real necessity to examine and look to the characteristics and mechanisms of action of newly developed antimicrobial components. One of the drawbacks of currently available medicines in the market is the development of resistance by pathogenic microorganisms against them. Plants are considered a rich source of antimicrobial agents that have been shown to be effective against a variety of pathogens. Taraxacum officinale is one of the many herbal plants that have antioxidant potential and can be considered a potential source for the removal of microbial agents [33-41].

\section{Conclusions}

The antioxidant activity of Taraxacum officinale has been evaluated from the determination of TPC in hydroalcoholic and aqueous extracts. The results declared that hydro-alcoholic extracts exhibited the greatest antioxidant activity as compared to aqueous extracts. The high foraging characteristics may be associated with the presence of hydroxyl groups $\left(\mathrm{OH}^{1-}\right)$ in the phenolic compounds. The phenolic contents of Taraxacum officinale portray the fact that the extract from this herbal plant may help discover new antibiotic substances for chemotherapy and control of chronic infectious diseases.

\section{Conflict of Interest}

The authors declare no conflict of interest.

Table 2. Total phenolic contents of Taraxacum Officinale L.

\begin{tabular}{|c|c|c|c|c|c|c|}
\hline S. No. & Extract & $\begin{array}{l}\text { Quantity } \\
(\mu \mathrm{g} / \mathrm{ml})\end{array}$ & Absorbance & $\begin{array}{c}\text { Phenolic contents } \\
\mathrm{mg} / \mathrm{ml}\end{array}$ & $\begin{array}{c}\text { Mean and standard } \\
\text { deviation }\end{array}$ & $\begin{array}{l}\text { Phenolic contents } \\
\text { (mg. GAE/g) }\end{array}$ \\
\hline \multirow{3}{*}{1} & \multirow{3}{*}{$\begin{array}{c}\text { Ethanolic- } \\
\text { Aqueous } \\
(50: 50)\end{array}$} & \multirow{3}{*}{1000} & 1.40 & 42.9166 & \multirow{3}{*}{$\begin{array}{l}38.458 \mathrm{SD} \\
\pm 3.92176\end{array}$} & \multirow{3}{*}{$691.6 \mathrm{mg} / \mathrm{g}$} \\
\hline & & & 1.22 & 35.5416 & & \\
\hline & & & 1.26 & 36.9166 & & \\
\hline \multirow{3}{*}{2} & \multirow{3}{*}{ Aqueous } & \multirow{3}{*}{1000} & 0.73 & 15.0833 & \multirow{3}{*}{$\begin{array}{c}\text { 20.736 S.D. } \\
\quad \pm 4.976\end{array}$} & \multirow{3}{*}{$41.47 \mathrm{mg} / \mathrm{g}$} \\
\hline & & & 0.91 & 22.6666 & & \\
\hline & & & 0.96 & 24.4583 & & \\
\hline
\end{tabular}


Khan A.S., et al.

\section{References}

1. RIZVIM.A., SAEED A., ZUBAIRY H.N. Medicinal Plants, History, Cultivation and Uses. Karachi: Hamdard Institut. Adv. Studies Res, 1-216, 2007.

2. SHETE H.G., KAPDNIS B.P. Cyanide hydratase production using acclimatized strain of Streptomyces phaeoviridae and its characterization. Int. J. Bioassays. 2 (8), 1098, 2013.

3. TUNÇ K., HOŞ A., GÜNEŞ B. Investigation of Antibacterial Properties of Cotinus coggygria from Turkey. Pol. J. Environ. Stud. 22 (5), 1559-1561, 2013.

4. NOOR A., KHATOON S., AHMED M. Ethnobotanical studies on some useful trees of Astore valley (GilgitBaltistan) Pakistan, with particular reference to medicinal uses. Int. J. Biol. Biotech. 10 (4), 565, 2013.

5. NOOR A., KHATOON S., AHMED M., RAZAQ A. Ethnobotanical studies on some useful shrubs of Astore valley Gilgit-Baltistan. Bang. J. Bot. 43 (1), 19, 2014.

6. PHULPOTO A.H., QAZI M.A., MANGI S., AHMED S. , HAQ I.U., PHUL A.R., KANHAR N.A. Bioremediation of Oil-Based Paint from Aqueous Media by Novel Indigenous Brevibacillus parabrevis Strain NAP3 and its Toxicity Assessment. Pol. J. Environ. Stud. 26 (1), 229, 2017.

7. SHAJAHAN A., RAMESH S. Antimicrobial Activity of Crude Ectocarp Extract of Pomegranate (Punica granatum L.) Against some selected Enteropathogenic Bacteria., As. J. Microbiol. Biotech. Env. Sci. 6 (4), 647, 2004

8. AYANDELE A.A., ADEBIYI O.A. The Phytochemical analyses and antimicrobial screening of extracts of Olax subscorpiodea. Afri. J. Biotech. 6 (7), 868, 2007.

9. OMAR O.C., KIRSTEEN O.P., ONYANGO DAVID M., ANTHONY S. Molecular clustering of microbial flora and Bacterial degradation of textile dyes by isolates from contaminated soils. Biotechnology. 54, 12452, 2013.

10. VAN DER KOOI C.J., PEN I., STAAL M., STAVENGA D.G., ELZENGA J.T.M. Competition for pollinators and intra-communal spectral dissimilarity of flowers. Plant Biology, 18 (1), 56, 2016.

11. NOOR A., KHATOON S., AHMED M. Enumeration of the ethnobotaniacal uses of some herbs in Astore Valley, Gilgit-Baltistan, Pakistan with particular reference to health cure purposes, Fuust J. Bio. 2 (2), 31, 2012

12. TILFORD G.L. Edible and Medicinal Plants of the West. $1^{\text {st }}$ Ed. Mountain Press, Missoula, MT. ISBN-10: 0878423591, 239, 1997.

13. ULLAH N., HAQ I.U., MIRZA B. Phytotoxicity evaluation and phytochemical analysis of three medicinally important plants from Pakistan. Toxicol. Ind. Health. 31 (5), 389, 2015.

14. ODOKUMA L.O., BEREBON D.P., OGBONNA C.B. Potential biodeteriogens of indoor and outdoor surfaces (coated with gloss, emulsion and textcoat paints). IOSR J. Pharm. Biol. Sci. 7 (1), 12, 2013.

15. KERSHAW L., COTTERILL P., WILKINSON S. Getting to Know Common Dandelions. The Alberta Native Plant Council, 2002

16. SOLBRIG OT. The population biology of dandelions. Am. Sci., 59, 686, 1971.

17. SANTO A., ZHU H., LI Y.R. Free Radicals: From Health to Disease. Reactive Oxygen Species 2 (4), 245, 2016.

18. FIGUEIRA T.R., BARROS M.H., CAMARGO A.A., CASTILHO R.F., FERREIRA J.C., KOWALTOWSKI A.J., SLUSE F.E., SOUZA-PINTO N.C., VERCESI A.E.
Mitochondria as a source of reactive oxygen and nitrogen species: from molecular mechanisms to human health. Antioxid Redox Signal 18 (16), 2029, 2013.

19. MARTINS N., BARROS L., FERREIRA I.C.F.R. In vivo antioxidant activity of phenolic compounds: Facts and gaps. Trend Food Sci. Technol. 48, 1, 2016.

20. CEDERBAUM A.I. Molecular mechanisms of the microsomal mixed function oxidases and biological and pathological implications. Redox. Biol. 4, 60, 2015.

21. MANDA-HANDZLIK A, DEMKOW U. Neutrophils: the role of oxidative and nitrosative stress in health and disease. Adv. Exp. Med. Biol. 857, 51, 2015.

22. VALKO M., JOMOVA K., RHODES C.J., KUCA K., MUSILEK K. Redox- and non-redox-metal-induced formation of free radicals and their role in human disease. Arch. Toxicol. 90 (1), 1, 2016

23. LIM Y.Y., LIM T.T., JING J. Antioxidant Properties of Guava Fruit: Comparison with Some Local Fruits, Sunway Acad. J. 3, 9, 2006.

24. SAVITREE M., ISARA P., NITTAYA S.L., WORAPAN S. Radical Scavenging Activity and Total Phenolic Content of Medicinal Plants Used in Primary Health Care. J. Pharm. Sci. 9 (1), 32, 2004.

25. POURMORAD F., HOSSEINIMEHR S.J., SHAHABIMAJD N. Antioxidant activity, phenol and flavonoid contents of some selected Iranian medicinal plants, Afr. J. Biotech. 5 (11), 1142, 2006.

26. IQBAL M., KHERA R.A., HUSSAIN T., SADIA H., ABBAS M., NAZIR A., ARSHAD M., YOUNAS U. Cytotoxicity and bioactivity evaluation of pygmy date palm extracts. Current Science Perspectives 3 (2), 106 2017.

27. KUMAR V., KUMAR V., BHALLA T.C. In vitro cyanide degradation by Serretia marcescens RL2b. Int. J. Environ. Sci. 3, 1985, 2013.

28. NIU Y., DEFOIRDT T., BARUAH K., VAN DE WIELE T., DONG S.,BOSSIER P. Bacillus sp. LT3 improves the survival of gnotobiotic brine shrimp (Artemia franciscana) larvae challenged with Vibrio campbellii by enhancing the innate immune response and by decreasing the activity of shrimp-associated vibrios. Vet. Microbiol. 173 (3), 279, 2014.

29. SUBATHRA M.K., IMMANUEL G., SURESH A.H Isolation and identification of hydrocarbon-degrading bacteria from Ennore creek. Bioinformation. 9 (3), 150, 2013.

30. MURTIĆ S., ČIVIĆ H., ĐURIĆ M., PAUNOVIĆ G., ŠEKULARAC G., BEHMEN F., KRSMANOVIĆ M. The Content of Some Antioxidants in Apple Depends on the Type of Fertilization. Pol. J. Environ. Stud. 22 (2), 475, 2013.

31. MILEK M., JAROSLAV L. Total Phenolic Content and Antioxidant Properties of Taraxacum officinale Extracts obtained with Different Solvents. Res. J. Chem. Env. Sci. 3 (6), 59, 2015.

32. IVANOV I.G. Polyphenols Content and Antioxidant Activities of Taraxacum officinale F.H.Wigg (Dandelion) Leaves, IJPPR. 6 (4), 889, 2015.

33. CHUN-LEI Z., LIANG L., CHUN-BO H., DONG-SHENG W. Biodegradation of acetaldehyde by microorganisms in biological activated carbon filters. J. Bioremediat. Biodegrad. 4 (184), 2, 2013.

34. SAFA M., ALEMZADEH I., VOSSOUGHI M. Biodegradability of oily wastewater using rotating biological contactor combined with an external membrane. J. Environ. Health Sci. Eng. 12 (1), 117, 2014. 
35. AZHDARPOOR A., MORTAZAVI B., MOUSSAVI G. Oily wastewaters treatment using Pseudomonas sp. isolated from the compost fertilizer. J. Environ. Health Sci. Eng. 12 (1), 77, 2014.

36. TURNER D.A., PICHTEL J., RODENAS Y., MCKILLIP J., GOODPASTER J.V. Microbial degradation of gasoline in soil: comparison by soil type. J. Bioremediat. Biodegrad. 5, 216, 2014.

37. TAMURA K., STECHER G., PETERSON D., FILIPSKI A., KUMAR S. MEGA6: molecular evolutionary genetics analysis version 6.0. Mol. Biol. Evol. 30 (12), 2725, 2013.

38. ROY A.S., BARUAH R., BORAH M., SINGH A.K., BORUAH H.P.D., SAIKIA N., DEKA M., DUTTA N., BORA T.C. Bioremediation potential of native hydrocarbon degrading bacterial strains in crude oil contaminated soil under microcosm study. Int. Biodeterior. Biodegr. 94, 79, 2014.
39. ALKOTAINI B., ANUAR N., KADHUM A.A.H., SANI A.A.A. Detection of secreted antimicrobial peptides isolated from cell-free culture supernatant of Paenibacillus alvei AN5. J. Ind. Microbiol. Biotechnol. 40 (6), 571, 2013.

40. MILILLO S.R., STORY R.S., PAK D., O'BRYAN C.A., CRANDALL P.G., RICKE S.C. Antimicrobial properties of three lactic acid bacterial cultures and their cell free supernatants against Listeria monocytogenes. J. Environ. Sci. Health B. 48 (1), 63, 2013.

41. COMPAORÉ C.S., NIELSEN D.S., OUOBA L.I., BERNER T.S., NIELSEN K.F., SAWADOGO-LINGANI H., DIAWARA B., OUÉDRAOGO G.A., JAKOBSEN M., THORSEN L. Co-production of surfactin and a novel bacteriocin by Bacillus subtilis subsp. subtilis $\mathrm{H} 4$ isolated from Bikalga, an African alkaline Hibiscus sabdariffa seed fermented condiment. Int. J. Food Microbiol. 162 (3), 297, 2013. 
